Fairly";"Relevance - Our Studies Must Aid Average People with Cancer"; "Affordability - Successful Therapies must be Broadly Available." Obviously, Prasad has chosen these goals as we currently fail to achieve them.

Although I've put it near the end of my discussion, Prasad opened with a story that was close to my heart and involved several close friends. Bone marrow suppression was often the dose-limiting toxicity in the treatment of breast cancer with regimens centred around alkylating agents, anthracyclines and taxanes. Yet it appeared that dose increments were still improving outcomes, even at the high end. It seemed reasonable that stem-cell autografts (preserving some marrow in storage, and giving it back after the marrow-toxic treatment had been given) would allow more intensive therapy and achieve greater benefit. After a pilot experience, enthusiasm was great, and the therapy became standard at some centres; at least one state in the US passed a law guaranteeing access.
But when a rigorous multicenter prospective controlled trial was finally carried out, the benefit was nowhere to be found. A good friend was the site principal Investigator at one participating centre; her simple summary (paraphrased): "I think we killed about the same number that we cured." Prasad's book asks: What went wrong, here? What can we learn from stories like this one? How can we do it better next time? He nudges us toward answers.

Although Prasad is himself a haematologist/oncologist and builds this narrative around cancer and cancer therapy, many of the conclusions are generalisable. This is a good read for anyone interested in medical evidence.

As befits the intended audience - a mixture of people in the field and people very much not in the field - the author provides a helpful bibliography. The work has extensive citations.

\title{
Are you being managed?
}

\author{
JON JUREIDINI
}

\section{Sergio Sismondo, Ghost-managed medicine: Big Pharma'sinvisible hands, Manchester, UK: Mattering Press; 2018. Pgs 152. ISBN: 978-0-9955277-7-5 (paperback), ISBN: 978-0-9955277-8-2 (e-book). $£ 16$ (paperback).}

(Open access; download available from: https:// www.matteringpress.org/wp-content/uploads/2018/07/

Sismondo-Ghost-managed-Medicine-2018-1.pdf)

There are at least 15 points of intervention by the pharmaceutical industry in the causal pathway from a TV ad to a prescription. Ghost-managed medicine exposes Big Pharma's calculated control of this pathway. Many of the interventions might appear to come from outside industry with contributions from seemingly independent researchers, medical experts, regulators and consumer organisations. But it is all carefully and ruthlessly orchestrated by industry; egregious examples from the United States include the

Author: Jonathan Jureidini (jon.jureidini@adelaide.edu.au), Research Leader and Child Psychiatrist, Robinson Research Institute, Adelaide University, Adelaide, South Australia, AUSTRALIA.

To cite: Jureidini J. Are you being managed? Indian J Med Ethics. $2021 \mathrm{Apr}-$ Jun; 6(2) NS: 178-179. DOI: 10.20529/IJME.2020.094.

Published online first on September 8, 2020.

Manuscript Editor: Sanjay A Pai

(C) Indian Journal of Medical Ethics 2020
Orwellian "patient advocacy" group, Centre for Medicine in the Public Interest, created as a voice for Big Pharma and controlled by it.

Sismondo's methodology was to attend what he describes as "penumbral" conferences that addressed, inter alia, marketing, management of key "opinion leaders" and publication planning. Here the tactics of industry are discussed with a frankness that is lacking in more academic forums. Sismondo and his collaborators collected rich data with many shocking narratives.

From time to time, Sismondo reminds us that industry science is not necessarily bad science; that input from the marketing division might not necessarily be corrupt because there is a correlation between a drug being marketable and being good. For example, he writes of publication planners: "they appeared to be trying to be honest and to be striving for sound science, while serving the interests of drug companies' marketing departments" (pp 89-90). The implication is that a system driven by profit rather than ethics might still be good for our health.

Sismondo's book covers some of the same ground as one I have recently published with philosopher Leemon McHenry (The illusion of Evidence-Based Medicine, Wakefield Press, 2020). We agree on most things but disagree with his implication that industry science might generally have good outcomes. We think the capitalist model of essentially unregulated science does unacceptable harm. Sismondo provides little 
evidence of good industry science and no effective defence against the allegation that the system is fatally flawed.

Among the strongest elements of Sismondo's book is his analysis of the role of "key opinion leaders" (KOLs), based on interviewing 14 individuals identified as KOLs, as well as listening carefully to what industry and publication planning figures had to say about them. Sismondo traces the origin of industry's use of opinion leaders to 1950s sociology research commissioned by Pfizer and deliberately withheld from the research literature in order to give them a head start on their competitors. Sales representatives are key to identifying potential KOLs; the ideal is a bright and ambitious young doctor whose views are already sympathetic to the company agenda. The KOL can then be groomed through support for research, teaching opportunities, and positions on advisory boards. As Sismondo notes, "repeatedly being billed as a leading expert can give a person the status of leading expert" (p138). Doctors who feel they are having a constructive influence on industry practice might be disappointed with Sismondo's finding that information gathered from advisory board members "was thrown away when the checks were handed out".

Sismondo rather understates the case when he says "the KOLs themselves probably do not see all the ways in which they are managed by drug companies" (p130). I prefer his characterisation of KOLs as zombies, "animated bodies sent out to do pharma's bidding". The best KOLs are those who are unaware that they are anyone's creation, those who are mostly proud of the way that they made use of industry without any impact on their own ideas. The process is demeaning to both parties. Sismondo reports, 'The reps laugh amongst themselves: The most comical thing is doctors' attitudes. You will never hear a physician say, "This is influencing me."They are just so arrogant and naïve." (p150)

The biggest trick of industry is to take away agency from someone who nevertheless gets the impression that their agency has been increased. It can be readily appreciated that a KOL, speaking with personal conviction about a drug, will be a much more powerful marketing tool than someone who is overtly identified as a marketing representative. This is particularly the case where the KOL's primary message is not to prescribe a particular drug, but rather to include it as part of an overall package - for example, management of cardiovascular risk in midlife, where lipid lowering drugs are portrayed as just part of a health enhancing package of "lifestyle changes". Companies can be confident that even if the KOL advocates some lifestyle change or non-drug therapy as the primary intervention with a seemingly conservative approach of relegating drugs to second line, the default position for many doctors in the target audience will be to prescribe. A good example is the promotion of off-label use of antidepressants for young people. Sales representatives are not permitted to detail off-label drugs, but no such restriction applies to KOLs. Australian KOLs, with long-standing but not always obvious links to industry, have promoted increased screening for and treatment of depression in young people, strongly supporting a role for antidepressants but not pushing them as first-line treatment. Industry knows that by far the most common intervention for depression in general practice is to prescribe medication so the net effect of a depression awareness programme will be increased sales of antidepressants even if the KOLs are not advocating drugs as first-line treatment.

It is hard to understand the failure of intelligent welleducated doctors to recognise that if something is too good to be true, it probably isn't. KOLs manage to turn a blind eye to the way in which they are being exploited. As the late Micke Nardo (See: http://1 boringoldman.com/index.php/ 2012/12/21/hideand-go-seek/) wrote:"It's always funny when small children try to play hide-and-go-seek by covering their eyes, but when grown-ups do it, it loses its charm." Ghostmanaged medicine is an antidote to such childish behaviour.

\title{
Pandemics as mirrors of society: The more things change, the more they stay the same
}

\author{
SAMIR MALHOTRA
}

\section{Frank Snowden, Epidemics and Society: From the Black Death to the Present, Yale University Press, 2019, 682 pages, \$35 (hardcover), ISBN 978-0-300- 19221-6.}

"...concept of the king's touch to cure disease. King Charles II of England ... administered the touch to nearly one hundred thousand people during the mid$1600 s . "$ : (p 31) In the 21st century, the touch of a godman can apparently make kidney stones come out of the mouth, not of the patient, but of the godman himself!

Historian Frank Snowden's book, Epidemics and Society: From the Black Death to the Present, based on the author's lectures at Yale University, provides an excellent opportunity to compare Covid-19 with pandemics across two millennia, and to contextualise the similarities/differences of stakeholders' responses. In a captivating narrative, Snowden first equips us 